\author{
Esa Konttinen ${ }^{\mathrm{a}}$, Miikka Salob \& Sakari Möttönen ${ }^{\mathrm{c}}$
}

\title{
Turvetuotannon sosiaalisen toimiluvan menetys Saarijärven reitillä
}

\section{The loss of the social license for peat harvesting in the Saarijärvi waterway}

Following the 1970s oil crisis the search for alternative energy sources intensified in Finland. As a result, peat harvesting from peat bogs was launched programmatically. This included peat bogs around the Saarijärvi waterway in central Finland, consisting today of about 50 peat harvesting sites. As in a number of cases, these peat harvesting operations are opposed by the local residents, who insist that peat harvesting is spoiling the waters, and thus damaging recreational activities like fishing, swimming, and the enjoyment of nature. The aim of our study was to investigate the situation in greater detail by eliciting local residents' experiences. In the fall of 2015 a questionnaire was sent to the residents of four municipalities in the area, producing 478 responses, a response rate of 23.9 per cent, which represents the local population fairly well. Peat harvesting was reportedly the most harmful source of water pollution. The results were analyzed using the concept of social license to operate. A generalization can be made that peat production in the district has largely lost local residents' approval.

Keywords: survey, Saarijärvi waterway, peat harvesting, social license to operate

\section{Johdanto}

\section{Turve kiistan kohteena}

Turvetuotanto on ollut kiistelyn kohteena siitä lähtien, kun turvetta alettiin nostaa energiatuotannon tarpeisiin. Kiista on viime vuosina kärjistynyt monilla alueilla konfliktin asteelle. Käsittelemme artikkelissamme kiistaa Saarijärven reittiä koskevan tapaustutkimuksen avulla selvittämällä asukkaiden suhtautumista turpeen nostoon.

Turvetta nostettiin energiantuotannon tarpeisiin Suomessa pienessä mitassa jo 1800-luvulla. Suomen turveteollisuuden ensimmäinen läpimurto koettiin toisen maailmansodan jälkimainingeissa vuosina 1945-1953, jolloin turpeen kanssa kilpailevan kivihiilen saanti vaikeutui vuosiksi sota-ajan jälkeenkin. Polttoturve jäi kuitenkin 1950- ja 1960-luvuilla ensin kivihiilen ja sen jälkeen erityisesti öljyn varjoon. (Ruuskanen 2010)

a. Jyväskylän yliopisto, esa.j.konttinen@gmail.com, b. \& c. Jyväskylän yliopisto 
Turpeen nostossa Suomen soilta seuraava käännekohta oli 1970-luvun puolivälin öljykriisi, joka kohdisti huomion öljylle vaihtoehtoisiin energianmuotoihin. Osaksi uutta ohjelmallista energiapolitiikkaa (Salo 2015, 27-31, 35-40) otettiin myös turve. Soita Suomessa on runsaasti, 9,3 miljoonaa hehtaaria, mikä on maan pinta-alaan suhteutettuna ylivoimaisesti eniten Euroopassa. Turpeen nosto soilta energian tuottamiseen sai nopeasti siivet alleen, vaikka energiantuotannon suurtekijää siitä ei ole tullut. Turpeen käytön ongelmia ovat olleet hintakilpailukyvyn lisäksi sopivien soiden löytäminen, tuotannon herkkyys säöolosuhteille, teknologia- ja työvoimakysymykset sekä 1970-luvulla voimistuneet soiden- ja vesiensuojelukysymykset (Ruuskanen 2010). Vuonna 2016 turpeen osuus energiankokonaiskulutuksesta oli 4,1 prosenttia (Tilastokeskus 2017a). Suuria turpeen tuotantomaakuntia ovat Etelä- ja PohjoisPohjanmaa ja keskisuuria Lappi, Satakunta, Keski-Suomi ja Pohjois-Savo (Flyktman 2009, sit. Leinonen toim. 2009, 43).

Turveteollisuuden toisen läpimurron aika 1970-luvulla oli samalla heräävän ympäristönsuojelutietoisuuden aikaa (Ruuskanen 2010, 124). Pääargumentteina turvetuotannon kannattajilla ovat olleet kotimaisen energian saanti, energian huoltovarmuuden parantaminen sekä paikalliset taloudelliset edut etenkin maaseudun syrjäalueilla. Hyötyinä pidetään paikallisen energian saantia, uusia työpaikkoja ja kuntien verotuloja. Vastustajat ovat kohdistaneet kritiikkiä alusta lähtien luonnonsuojelullisin perustein turpeennoston uhkiin suoluonnolle. Vähitellen alettiin tuoda esiin turvetuotannon kielteisiä vesistövaikutuksia. Vesien käyttäjät katsoivat, että turpeennostosta aiheutunut veden pilaantuminen tuottaa veden virkistyskäyttöön ja kalastukseen liittyviä ongelmia. Ilmastokritiikki tähdentää turpeen polton päästöjen olevan kivihiilen energiakäyttöä pahemmat. Turpeen noston haitoista käydään kiistelyä muun muassa lehtien palstoilla ja lupien viranomaiskäsittelyssä. Näkökannat eivät ole lähentyneet toisiaan (Tupala 2014; Albrecht 2015; Lilleberg, 2015, 27-55). Keski-Suomessa turvekeskustelu kiihtyi vuoden 2007 lopulla, kun turvetuotannon lisäämisen mahdollistamaa kolmatta vaihemaakuntakaavaa alettiin valmistella (Syrjämäki 2013, 2-3). Kiistely ei osoita laantumisen merkkejä.

Julkisuudessa esitetyt eriävät näkökannat koskevat osaltaan siis turpeen nostamisen tuottamia vesistöongelmia. Turvetuottajien etujärjestö Bioenergia ry, joka kertoo edistävänsä bioenergian ja turpeen käytön yleisiä edellytyksiä, vetoaa lupaehtojen mukaisiin mittauksiin, joiden se katsoo osoittavan vesistöpäs̈söjen olevan vähäisiä ja hallittavissa (Leinonen toim. 2009, 66-73). Myös suurin turvetuottajayhtiö Vapo Oy korostaa omassa informaatiossaan (Vapo 2017), että turvetuotannossa käytetään parhaita mahdollisia vedenpuhdistusmenetelmiä, jotka estävät likaavien vesien pääsyn vesistöihin.

Kriittisesti turpeen nostoon suhtautuvat eivät luota mittauksiin väittäen niiden jättävän huomiotta muun muassa runsassateiset kaudet ja äkilliset tulvatilanteet, joiden aikana tapahtuvia suuria päästöjä normaalitilanteen mittaukset eivät rekisteröi. Myös hienojakoisen turvepölyn on sanottu johtavan lisääntyvään hapenkulutukseen ja vesistöjen rehevöitymiseen. Epäilyjä on seurannut myös siitä, että päästömittausten tekovelvoite on turpeen tuottajilla itsellään. Monilla seuduilla on syntynyt organisoituneita kansalaisryhmiä vastustamaan turvetuotantoa luontoarvojen kärsimisen ja luonnon virkistyskäytön vähenemisen sekä koettujen vesistövaikutusten vuoksi. Kriittistä tietoa turvetuotannosta ovat tuoneet esiin muun muassa Suomen Luonnonsuojeluliitto (2013) ja Pelastetaan reittivedet -yhdistys (2017).

\section{Tutkimuskohteena asukkaiden suhtautuminen turvetuotantoon}

Turpeen noston vesistövaikutuksia on tutkittu lähinnä luonnontieteellisillä menetelmillä. Paikallisten asukkaiden vesistöhavaintoja ja suhtautumista turvetuotantoon ei ole juurikaan tieteellisesti eritelty. Harvoja poikkeuksia ovat Syrjämäen (2013) ja Albrechtin (2015) haastattelututkimukset, Mustosen (2013) asukkaiden tekstinarratiiveihin perustuva tutkimus sekä Riipisen (2018) Saarijärven reitin asukkaiden mielipiteitä vesienhoidosta, vesien tilasta ja vesien tilan muutoksesta kartoittanut kyselytutkimus. Myös niissä on tullut esille turvetuotantoa koskevat ristiriitaiset näkemykset. Systemaattista yleistyksiin pyrkivää tutkimustietoa asukkaisen käsityksistä ei ole ollut. Olemme täyttäneet tätä tutkimusaukkoa tekemällä kyselytutkimuksen Saarijärven reitin varrella olevien asukkaiden reitin veden laatua ja muutoksia koskevista näkemyksistä (Möttönen ym. 2016, jatkossa tutkimusraporttiin viitataan tunnuksella R). Saarijärven reitti on valittu tutkimuskohteeksi sen vuoksi, että reitin vaikutusalueella on runsaasti turpeennostoa ja turvetuotannon vaikutuksista reitin veden laatuun käydään vilkasta keskustelua. 
Halusimme saada asukkailta tietoa yleisesti kyseisen vesistöjen tilasta ja veden laatuun vaikuttavista tekijöistä, emme pelkästään turvetuotannon vaikutuksista.

Kyselyyn vastanneista 61 prosenttia katsoi Saarijärven reitin tilan huonontuneen ja vain 8 prosentin mielestä huononemista ei ollut tapahtunut (ks. kuvio 1). Tutkimuksen keskeisenä tuloksena voidaan pitää sitä, että paikalliset asukkaat katsovat vesien tilan huonontuneen, ja että asukkaat pitävät turvetuotantoa (ks. kuvio 2) päällimmäisenä veden tilan huononemisen syynä (R, 55-56).

Kyselytutkimuksen tulos, jossa valtaosa vastaajista koki turvetuotannon vesistön huononemisen suurimpana aiheuttajana, oli tutkimuksellisesti uusi, mutta ei julkisen keskustelun perusteella yllättävä. Joka tapauksessa tutkimus synnytti tarpeen selvittää tarkemmin sitä, minkälaisesta ilmiöstä asukkaiden ja turvetuotannon suhteessa on kyse. Tässä artikkelissa tarkastelemme aineistomme perusteella turvetuotannon hyväksyttävyyttä paikallisten ihmisten näkökulmasta. Käytämme turvetuotannon hyväksyttävyyden analysoinnissa hyväksi sosiaalisen toimiluvan käsitettä ja teoriaa. Sosiaalisen toimilwvan käsite soveltuu tutkimusaiheemme käsittelyyn, koska sen lähtökohtana on jonkin hankkeen vaikutuspiirissä olevat toimijat ja heidän näkemyksensä hankkeen vaikutuksista. Tutkimme siis, onko turvetuotannolla paikallisilta asukekailta saatua sosiaalista toimilupaa alueella, jolla turvetuotantoa esiintyy laajamittaisesti.

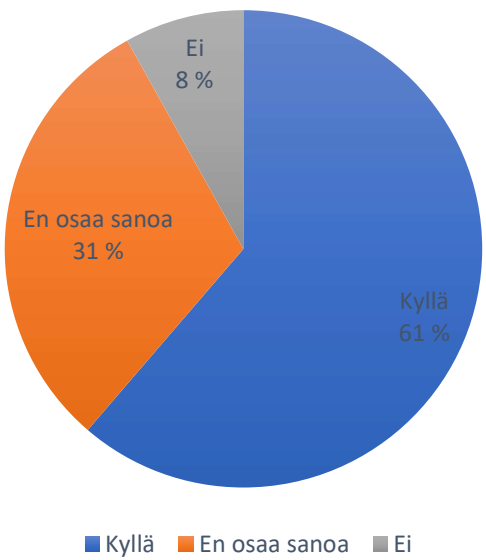

Kuvio I.Vastaajien näkemykset väitteeseen "Saarijärven reitin jokien ja/tai järvien tila on mielestäsi huonontunut” $(n=444)$ Figure I. Respondents' views on the claim "the state of the rivers and / or lakes on the Saarijärvi waterway has deteriorated" $(n=444)$

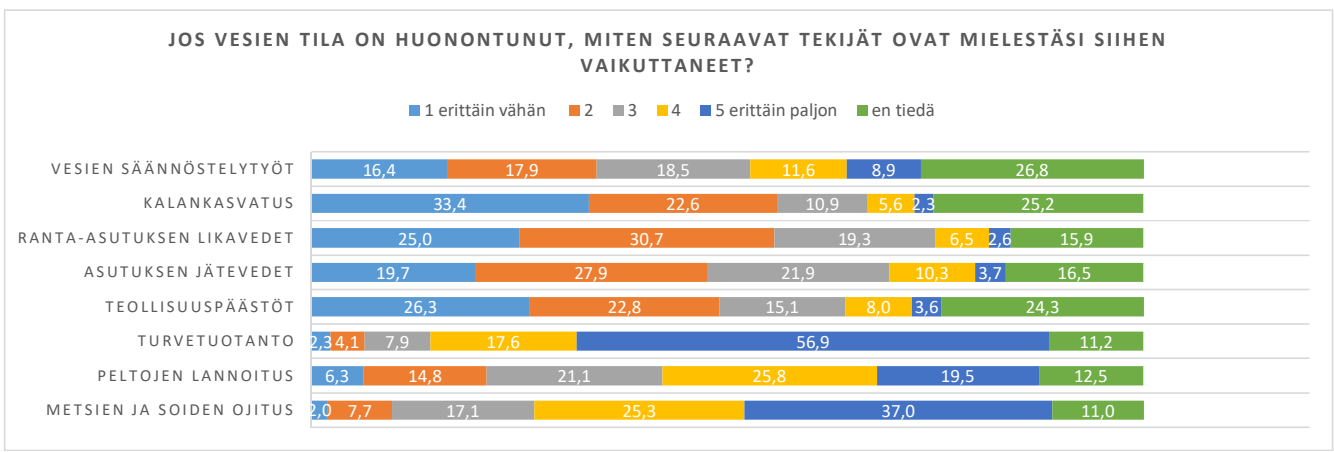

Kuvio 2 Vesien tilan huononemiseen vaikuttaneet tekijät $(\%, \mathrm{n}=336-392)$

Figure 2. Factors contributing to the degradation of the waters $(\%, n=336-392)$ 


\section{Sosiaalinen toimilupa}

Sosiaalisella toimiluvan käsitettä ja teoriaa on sovellettu ympäristöön vaikuttavan toiminnan hyväksyttävyyden analysointiin. Käsitteen juuret ovat kaivannaisteollisuushankkeissa. Hankekehittäjät ovat eri puolilla maailmaa kiinnittäneet huomiota paikalliselta väestöltä saadun epäviralliseen hyväksynnän tärkeyteen hanketta suunniteltaessa ja toteutettaessa. Hanketta ajavat yritykset haluavat varmistaa hankkeen sujuvuuden ja toimia vähentääkseen sen sosiaalisia ja ympäristölle koituvia haittoja (Bice \& Moffat 2014, 257). Sosiaalinen toimilupa -termi luotiinkin alun perin yritysmaailmassa 1990-luvun lopulla, kun kanadalaisen kultakaivosyhtiön johtaja oli havainnut yritysten usein menettävän taloudellisia hyötyjä rikottuaan suhteensa paikallisyhteisöön ympäristöä vaurioittamalla. Tältä perustalta syntyi tarve parantaa suhteita paikallisyhteisöön (Boutilier 2014, 263). Menettelyn on katsottu nopeuttavan hankkeen toteutusta ja säästävän kustannuksia.

Hankeosapuolten kiinnostus asiaan on johtanut myös tutkijat erittelemään tarkemmin sosiaalista toimilupaa, sitä mitä sillä tarkoitetaan, sen luonnetta sosiaalisena sopimuksena, kriteereitä ja vahvuusasteita sekä mahdollisuuksia arvioida sosiaalisen toimiluvan voimassaoloa hankkeen kestäessä (käsitteestä Bice \& Moffat 2014; Boutilier 2014; Hall ym. 2015; Litmanen ym. 2016; käsitteen käyttöönotosta, Boutilier 2014, 263-264).

Sosiaalinen toimilupa ei ole muodollista sopimista, vaan kyse on paikallisen asujaimiston ja muiden asianosaisten osapuolten hyväksynnästä hankkeelle. Hyväksyntä ja siis sosiaalinen toimilupa voidaan myös menettää hankkeen kestäessä. Hankkeen toteuttajan, kuten kaivosyhtiön, on jatkuvasti ansaittava sosiaalinen toimilupa omalla toiminnallaan.

Yleisemmin sosiaalisella toimiluvalla tarkoitetaan hankkeen aikana alati katkolla olevaa paikallisyhteisön hyväksyntää hankkeelle, mikä voi myös vaikuttaa hankkeen kannattavuuteen (Bice \& Moffat 2014). Sosiaalisen toimiluvan käsitettä on alettu käyttää myös paikallista laajemmissa, kuten alueellisissa ja kansallisissa yhteyksissä (Hall ym. 2015, 302). Kansalliseen tasoon turpeennoston liittää esimerkiksi energian huoltovarmuuden näkökohta kriisiaikoina, joskin alan osuus ei energian kokonaiskulutuksen kannalta ole kovinkaan merkittävä. Suoluonnon suojelun tarpeet voivat liittää sen paikallisen ja kansallisen tason lisäksi kansainväliseen tasoon lajien säilymisen ja luonnon monimuotoisuuden ylläpitämisen kautta.

Viime vuosina sosiaalisen toimiluvan käsite on levinnyt myös muualle, kuten eri energiateollisuuden alueille (Hall ym. 2015). Turpeennoston alueelle käsitettä ei kuitenkaan ole aikaisemmin tietääksemme sovellettu. Tämä johtunee muun muassa turvetuotannon suhteellisen vähäisestä määrästä Suomen ulkopuolella. Käsite kuitenkin näyttää soveltuvan hyvin turpeennoston hankkeisiin, koska näissä hankkeissa niin hankkeesta hyötyjät kuin myös haitankärsijät ovat paikallisia, ja hankkeen näin ollen voidaan katsoa olevan suuressa määrin "paikallinen asia". Sen sijaan, jos hankkeella on suuria yleisempiä, kuten valtakunnallisia arvoja ja haittoja, paikallinen merkitys voi olla suhteellisesti vähäisempi ja niin myös paikallisyhteisön kannalta sosiaalisen toimiluvan merkitys hankkeesta päätettäessä saattaa olla pienempi. Silloin hankkeen ominaislaatu yhteiskunnallisena ilmiönä kasvaa paikalliseen nähden. Myös siinä määrin kuin vaikutukset ovat toimialan yrityksille yleisiä, kysymys toimiluvasta laajenee yhteiskunnalliseen suuntaan. Siitä voi tulla alan legitimiteettiä koskeva kysymys (ks. Peltonen 2016).

Sosiaalinen toimilupa nähdään usein yritys- ja hankekohtaisena. Tässä suhteessa asetelmamme poikkeaa käsitteen yleisestä käytöstä. Turvetuottajia Saarijärven reitin alueella on noin 50 eikä tutkimuksemme erottele heitä. Tarkastelumme koskee siten turpeentuotantoa tuolla alueella koskevaa eräänlaista "kollektiivista sosiaalista toimilupaa" ja jonkinlaista "yleistettyä turpeennostajayritystä", joka muodostuu summana kokemuksista alueen turvetuottajista. Niistä tärkein on Vapo oy. Perusasetelma ei muutu sosiaalisen toimiluvan käsitteen näkökulmasta siinä mielessä, että kysymyksessä on tietyn yritystoiminnan kohdeyhteisö ja enemmän tai vähemmän yhtenäinen vesistö, joka levittää vesistömuutosten vaikutuksia valuma-alueelle tuotantopaikoista eteenpäin. Tarkempi tutkimus voi ottaa tarkasteluun yksittäiset yritykset ja sen onko niiden välillä havaittavissa eroja vesistövaikutuksissa ja sosiaalisen toimiluvan tekijöissä.

Sosiaalisen toimiluvan toteutumiseen vaikuttavat useat tekijät. Moffat ja Shang (2014, 62) esittävät empiiriseen tapaustutkimuksensa perusteella, että sosiaalinen toimilupa syntyy seuraavien pääelementtien perustalta: (1) hankkeen myönteiset ja kielteiset vaikutukset sosiaaliseen infrastruktuuriin, jolla tarkoitetaan laaja-alaisesti elämisen laadun tekijöitä kohdeyhteisössä; paikallisen yhteisön asujaimiston 
kanssakäyminen yrityksen kanssa (2) määrällisessä ja (3) laadullisessa merkityksessä, sekä (4) yrityksen toiminnallisen reiluus (fairness). Tekijöiden positiivinen arvo synnyttää luottamusta, joka johtaa hankkeen hyväksyntään ja arvostukseen. Juuri luottamus on Moffat' $n$ ja Shangin mukaan sosiaalisen toimiluvan keskeinen elementti.

Sosiaalisessa toimiluvassa on aste-eroja. Hankkeen vaikutuksen alaiset voivat sosiaalisen toimiluvan voimassaolon alimmalla tasolla enemmän tai vähemmän vastahakoisesti vain sietää hanketta, jonka tuntevat itselleen vieraaksi joko huomattavien haittojen takia hyötyihin nähden tai kokiessaan hankkeen ylipäätään yhdentekeväksi. Sitä korkeammalla tasolla hankkeeseen suhtaudutaan suopeasti eli se hyväksytään enemmän tai vähemmän selvästi myönteisenä asiana. Korkeimmalla tasolla hanketta arvostetaan niin, että siitä muodostuu jopa osa alueen ja asujaimiston identiteettiä. (Mononen \& Suopajärvi toim. 2016, 14.). Tälle ylimmälle tasolle on ominaista paitsi kokemus hankkeen suurista hyödyistä, myös vahva luottamus hanketta ajavaan yritykseen ja sen toteuttamiin toimenpiteisiin hyötyjen hankinnassa. Moffat'n ja Schangin (2014) nimeämät neljä kriteeriä saavat korkeimmalla asteella kaikki korkean positiivisen latauksen, ja paikallisten hanketta puoltava motivaatio on korkea. Sosiaalisen toimiluvan heiketessä jotkut tai kaikki kriteerit menettävät korkeaa lataustaan ja joutuvat epäilyksen kohteeksi. Luottamus hanketta ajavaan yritykseen myös laskee. Yritys tosin voi toimia avoimesti ja reilulla tavalla, vaikka hanke olisikin epätoivottava paikallisten asukkaiden mielestä.

Se, milloin sosiaalinen toimiluvan katsotaan olevan voimassa, tai missä on voimassaolon raja, on luonnollisesti keskeinen, mutta myös ongelmallinen kysymys. Tarvitaanko esimerkiksi paikallisyhteisön, kuten kunnan, asukkaiden enemmistö hyväksymään tai epäämään voimassaolo? Yleispätevää normia on ehkä mahdotonta antaa, mutta pulmaa on ehdotettu lähestyttäväksi asianosaisuuden näkökulmasta. Boutilier $(2014,269)$ kysyy, millainen painoarvo eri asianosaisilla (stakeholders) tulisi olla sosiaalisen toimiluvan voimassaoloa päätettäessä. Hankkeet nimittäin koskettavat eri tavoin paikallisyhteisön jäseniä. Hän ehdottaa ratkaisun avaimeksi sitä, että yhteisön tai yhdyskunnan käsite korvattaisiin asianosaisten verkoston käsitteellä. Asianosaisella tarkoitetaan yksilöä, ryhmää tai organisaatiota, joka vaikuttaa hankkeeseen ja on sen vaikutuksen alainen. Samankaltaisia näkökantoja ovat esittäneet muutkin (ks. Litmanen ym. 2016, 783). Yleensä erityisasemassa on hankkeen paikallisyhdyskunnan asujaimisto.

Tässä tutkimuksessa pidämme sosiaalisen toimiluvan käsittelyn perustana Sairisen (2015) esittämää kaivostoimintaa koskevaa määritelmää. Sairisen mukaan "sosiaalinen toimilupa viittaa abstraktiin, kirjoittamattomaan ja epäviralliseen paikallisybteisön kanssa aikaan saatuun byväksyntään, joka mabdollistaa kaivostoiminnan aloittamisen ja ylläpitämisen". Artikkelissamme etsimme vastausta siihen, onko turvetuotannolla määritelmän mukainen Saarijärven reitin kuntien asukkailta saatu sosiaalinen toimilupa.

\section{Saarijärven reitti tutkimuskohteena}

Saarijärven reitti sijaitsee Kymijoen vesistön yläosassa pääosin Keski-Suomen maakunnan alueella. Saarijärven vesistöreitin vedet lähtevät Suomenselän suoalueilta, mikä tekee vesistä luonnostaan humuspitoisia. Reitin kokonaispinta-ala on $3120 \mathrm{~km}^{2}$, josta maapinta-alaa on noin $2800 \mathrm{~km}^{2}$. Alueen maapinta-alasta yli 25 prosenttia on suota. Alueella on runsaasti turvetuotantoa, kaikkiaan 50 turvetuotantoaluetta (Högmander \& Pehkonen 2014).

Saarijärven reitin vesien tilaa on tutkittu ekologisilla luokitusmenetelmillä. Ekologinen luokitus kuvaa vesien biologista tilaa ja ihmistoiminnan vaikutuksia vesien kuntoon. Suomen järvet, joet ja rannikkoalue on luokiteltu vuosien seurantatulosten perusteella viiteen Suomen ympäristökeskuksen laatimien laatuluokkakriteerien mukaiseen luokkaan: erinomainen, hyvä, tyydyttävä, välttävä ja huono (Suomen ympäristökeskus 2017). Biologisen aineiston puuttuessa asiantuntija-arvio on pyritty tekemään veden laadun ja ihmistoiminnan vaikutusten perusteella. Saarijärven reitillä järvistä lähes 60 prosenttia on pintavesien ekologisen tilansa perusteella luokiteltu tyydyttävään tai sitä huonompaan tilaan. Reitin ongelmallinen tilanne on Keski-Suomessa tunnistettu myös siten, että on käynnistetty hankkeita, joissa on etsitty keinoja parantaa veden laatua. Merkittävä oli Ely-keskuksen johtama monien toimijoiden yhteistyöhanke "Turvetuotannon ja metsätalouden vesien suojelun kehittäminen" (TASO). Hanke kohdistettiin Saarijärven reitin alueelle, koska reitin vesistö oli todettu olevan Keski-Suomen heikoin (Högmander \& Pehkonen 2014, 8) 
Saarijärven reitin vesistö Kyyjärven, Karstulan, Saarijärven ja Uuraisten kuntien alueella ja veden laatuluokiteltu tila näkyy kartassa 1.

\section{Tutkimuksen aineisto ja menetelmät}

Artikkelissa käytetty empiirinen aineisto perustuu edellä mainittuun tutkimusraporttiimme. Tutkimuksen aineisto kerättiin Väestörekisterikeskuksen otannalla Saarijärven reitin kuntien, Kyyjärven, Karstulan, Saarijärven ja Uuraisten yli 18 vuotta täyttäneistä asukkaista. Otoksen suuruus oli 2000 henkilöä. Joukkoon otettiin sekä vakituisia asukkaita että niitä, jotka omistavat vapaa-ajan asunnon jossain alueen kunnista, mutta joiden kotikunta on jokin muu kunta. Otoksessa tehtiin kuntakohtaisia painotuksia siten, että oli mahdollista saada kummastakin ryhmästä tilastollisesti merkitseviä tuloksia. Otoksen kuntakohtainen jakautuminen on esitetty liitetaulukossa 1.

Lomakkeet lähettiin marraskuun 2015 alussa. Vastauskuoria palautettiin kaikkiaan 486 eli palautusprosentti oli 24,3. Varsinaisia vastaajia oli 478, jolloin vastausprosentti on 23,9.

Vastaajista miehiä oli 273 eli 58 prosenttia ja naisia 200 eli 42 prosenttia. Vastanneiden kotikuntajakauma on esitetty liitetaulukossa 2.



Kartta I.Turvetuotantoalueet ja vesien laatu Saarijärven reitillä. Muokattu pohja-aineistoon SYKE/Vesikartta (Suomen ympäristökeskus 20I5) sekä Tilastokeskus/Avoimet karttapohjat (Tilastokeskus 20I7b)

Map I. Peat production areas and the quality of the waters in the Saarijärvi waterway 
Vastausten määrän perusteella pystyttiin muodostamaan kokonaiskuva reitin varren asukkaiden vesien tilaa ja muutosta koskevista käsityksistä. Myös kuntakohtaisia vertailuja voidaan tehdä, mutta ei esimerkiksi järvi- tai turveyrittäjäkohtaisia. Vastaajien taustatietojen ja kuntakohtaisten väestötietojen perusteella emme havainneet mitään olennaista, mikä asettaisi saatujen tietojen yleistettävyyden kyseenalaiseksi (ks. R, 18-23). Aineistossamme iäkkäät tosin ovat jonkin verran yliedustettuja.

Tutkimusraportissa kuten myös tässä artikkelissa tulokset esitetään taulukoina ja kaavioina. Pääasiallisena menetelmänä on käytetty ristiintaulukointia, minkä lisäksi esitetään korrelaatioita ja näihin kytkeytyviä merkitsevyystestejä.

Tutkimuslomakkeessa oli osio, johon pyydettiin vastaajia kertomaan heidän itsensä tekemiä havaintoja ja kokemuksia vesistön tilasta. Avoimia vastaukset, joita oli hieman yli puolessa lomakkeista, luettiin ja ryhmiteltiin siten, että niitä voitiin ottaa raporttiin täydentämään kuvioissa ja taulukoissa olevia määrällisiä tietoja. Koska avoimia vastauksia käytettiin täydentävänä aineistona, aineiston käsittelyä sisällönanalyyttisillä menetelmillä ei katsottu tarpeelliseksi. Tässä artikkelissa käytämme avoimia vastauksia kuvailemaan määrälisen aineiston esiin tuomia asiantiloja.

Asukkaiden omakohtainen kokemus vesistöstä on aineistonkeruumme lähtökohta. Halusimme tiedonhankintamme empiirisesti vahvemmaksi verrattuna yleisiin asennemittauksiin, joissa epämääräisempi mutu-tieto esittää keskeistä osaa. Kyselymme vastaajat ovat vesistönvarren asukkaita ja tutkimamme vesistön käyttäjiä arkielämässään. Suurin osa heistä on asunut pitkään alueella - 88,1\% vastaajista ilmoitti asuneensa yli 10 vuotta nykyisessä asuinkunnassaan. Yli 80 prosenttia vastaajista sanoo "säännöllisesti seuranneensa jonkin järven tai luontoympäristön tilaa". Kun kysyttiin, mistä asukkaat ovat saaneet tietoa vesistöreitin tilasta ja tilaan liittyvistä kysymyksistä, suurin osa (noin 60 prosenttia) arvioi tärkeimmän kahden tietolähteen joukkoon omat havainnot. Vain tiedotusvälineiden merkitys nousi samalle tasolle (R, kuvio 19, s. 51). Myös avoimissa vastauksissa oli paljon kuvauksia asukkaiden omista vesistökokemuksista ja havainnoista.

Tutkimuksemme tiedonhankintaa ei suunniteltu sosiaalisen toimiluvan käsitteen näkökulmasta. Vasta tutkimustulos turpeen nostosta suurimpana koettuna ongelmanlähteenä toi lähemmin mielenkiinnon kohteeksi sosiaalisen toimiluvan käsitteen. Tutkimuksen suuntaaminen tässä artikkelissa muistuttaakin aineistolähteistä asetelmaa. Siinä aineistosta tehdyt löydöt suuntaavat huomion tutkittavan ilmiön kyseiseen puoleen, jota sitten ryhdytään jäsentämään ja aineistoa hyödyntämään löytöä koskevin teoreettisin käsittein (Layder 1998). Tilanne on tutkimuksen kannalta tyydyttävä, koska kyselyaineisto sisältää sosiaalisen toimiluvan käsitteen tarkasteluun soveltuvaa tietoa. Niin ikään otoksemme koskee juuri asianosaisia ja heidän ydinryhmäänsä, vesistön varrella asuvia. Otoksen avulla on mahdollista tavoittaa hankkeen vaikutuspiirissä olevan, tuhansiin nousevan väestön näkökantoja ja kokemuksia.

Käytämme analyysissä hyväksemme korrelaatiokertoimia. Käyttämämme korrelaatiokerroin ilmoittaa kahden tekijän yhteisvaihtelun vahvuuden eli muuttujien välisen tilastollisen riippuvuuden. Karkeasti voidaan sanoa, että korrelaatiokertoimen arvo $r=.30$ ilmaisee selvää riippuvuutta sosiaalisten ilmiöiden osalta. Samassa yhteydessä lasketaan riippuvuuden merkitsevyys, jolla varmistetaan, että riippuvuus ei ole satunnaista. Korrelaatiokertoimen p-arvo kertoo todennäköisyyden sille, että muuttujien välinen yhteys johtuisi sattumasta. Korrelaatiolaskuissa käytetään Spearmanin järjestyskorrelaatiokerrointa, jonka käyttö määräytyy kysymyksen mitta-asteikon tasosta.

\section{Tutkimuksen tuloksia}

\section{Asukkaiden intressi Saarijärven reitin vesistöihin}

Kyselyssä pyydettiin arviota Saarijärven reittivesien tilasta koko Saarijärven reitiltä, oman kylän vesistöstä ja lähimmästä järvessä (ks. kuvio 3).

Asukkaiden mukaan reitillä on erittäin hyvä- ja huonokuntoisia vesialueita sekä kaikkea siltä väliltä. Arviot kuitenkin painottuvat ongelmia ilmentävään suuntaan. Reitin varren asukkaista 41 prosenttia piti tilannetta lähimpänä olevassa järvessä tai joessa välttävänä tai huonona, 75 prosenttia korkeintaan tyydyttävänä ja alle 20 prosenttia hyvänä tai erinomaisena (ks. kuvio 3). Arviot Saarijärven reitin tilasta ovat samansuuntaisia vesiviranomaisten vesien laatuluokitusten ja Riipisen $(2018$, 29) tutkimuksen tulosten kanssa. 
Tuomme tarkasteluun lisätekijän, joka liittyy kiinteästi sosiaalisen toimiluvan tarkoittamaan ilmiöön. Tämä tekijä on asianosaisen asujaimiston motiivit, jolla viittaamme paikallisen asukkaiden hankkeen hyväksyntää / hylkäämistä ohjaaviin merkityksiin ja intresseihin. Motiivit valottavat kysymystä sosiaalisen toimiluvan määräytymisestä. Myönteisten ja kielteisten vaikutusten keskinäinen punnitseminen tapahtuu suhteessa siihen, mikä asukkaille on tärkeää hankkeen tuottamissa vaikutuksissa. Tärkeää koskevat määritykset tehdään asukkaiden arjessa, jonka yksi keskeinen elementti on fyysinen ympäristö.

Lähes puolet vastanneista märitti alueen luonnon virkistyskäytön merkityksen itselleen erittäin suureksi (ks. kuvio 4). Vesistöillä on tässä keskeinen osuutensa, sillä melkein yhtä suuri osa (40 prosenttia) määritteli alueen vesistöjen merkityksen erittäin suureksi. Koska kannan märittäminen kohdistettiin Saarijärven reittiin, myöskään valittu pieni merkitys -vaihtoehto ei sulje pois sitä, että vesistö on näin vastanneille tärkeä jossain reitin ulkopuolella. Suurin osa ilmoitti vesiympäristöön liittyvistä virkistysmuodoista useamman kuin yhden, kuten uimisen, mökkeilyn, maisemien katselun, veneilyn, saunomisen, kalastuksen toteutuvan kohdallaan. Avoimissa vastauksissa vesistöjen merkitys virkistyskäytössä vielä korostui. Asukkaat kuvailivat luonnon ja virkistyskäytön merkitystä toteamalla esimerkiksi, että "luonto on äärimmäisen tärkeä virkistäytymisen lähde" ja että "kirkas, kaunis vesistö, luonto, metsät - minun Suomi" (R, 26). Alueen vesistöjen virkistyskäyttö kuuluu kiinteästi paikallisen asujaimiston suuren osan elämäntapaan.

Luonnon kokemisen ja turvetuotannon koetun ongelmallisuuden välillä on selvä yhteys. Taulukossa 1 on tarkasteltu koetun luonnon merkityksen (kuvio 4) yhteyttä siihen, kuinka paljon vastaaja katsoo turvetuotannon vaikuttaneen vesistöjen tilan huononemiseen (huononemisesta ks. kuvio 2: Jos vesien



Kuvio 3. Arviot Saarijärven reitin vesistön tilasta $(\%, \mathrm{n}=421,425,437)$

Figure 3.The condition of the waters in the Saarijärvi waterway as estimated by local residents (\%)

\section{MILLAINEN ON SAARIJÄRVEN REITIN JOKIEN JA/TAI JÄRVIEN MERKITYS SINULLE?}

$\square 1$ erittäin pieni $\quad \mathbf{2} \quad \square \quad \square \quad \square \quad \square$ erittäin suuri

ALUEEN LUONNON VIRKISTYSKÄYTÖN MERKITYS MINULLE ON

ALUEEN SUOLUONNON MERKITYS MINULLE ON

ALUEEN VESISTÖJEN MERKITYS MINULLE ON

\section{$4,43,7 \quad 14,6 \quad 30,7$}

$10,9 \quad 13,6 \quad 25,4$

22,3

Kuvio 4. Saarijärven reitin merkitys asujaimistolle (\%, $n=459,457,46 \mathrm{I})$

Figure 4. Significance of the Saarijärvi waterway for local residents $(\%, n=459,457,46 I)$ 
Taulukko I. Luonnon merkitys asukkaille ja turvetuotannon koettu ongelmallisuus, korrelaatiot $(n=34 I-348)$

Table I. Significance of the natural environment for the residents and the perceived problems caused by peat harvesting, correlations $(n=34 I-348)$

\begin{tabular}{|l|l|}
\hline & Turvetuotanto huonontanut reitin vesistöjä \\
\hline Alueen luonnon virkistyskäytön merkitys & $r=.33$ \\
\hline Alueen suoluonnon merkitys & $r=.25$ \\
\hline Alueen vesistöjen merkitys & $r=.31$ \\
\hline
\end{tabular}

Spearmanin järjestyskorrelaatiokerroin r. Korrelaatio on kaikkien kolmen tekijän osalta erittäin merkitsevä $(p=.000)$.

tila on huonontunut, miten turvetuotanto on siihen vaikuttanut).

Mitä suurempana luonnon ja vesistön virkistysmerkitys koetaan, sitä ongelmallisempana turpeennoston haitat arvioidaan. Kysymys on osaltaan siitä, että jo koetut ongelmat ovat herkistäneet vastaajia: virkistysarvojen merkitykseen on havahduttu niiden osittaisen menetyksen tai niitä koskevan uhan kautta.

\section{Turpeennoston koettuja ongelmia virkistyskäytölle}

Aineistomme mahdollistaa koettujen haittojen tarkemman erittelyn. Tarkastelemme ensin korrelaatioiden avulla vastaajien käsityksiä siitä, mitä veden laadun huonontuminen turvetuotannon seurauksena heille tarkoittaa. Sen jälkeen tutkimme turpeennostoon kohdistuvia toiveita ja vaatimuksia. Päädymme lopuksi sosiaalisen toimiluvan ydinkysymykseen hyväksynnästä / hylkäämisestä.

Eri tekijöiden vertailussa (kuvio 2) turpeennosto arvioitiin suurimmaksi vesiä pilaavaksi lähteeksi Saarijärven reitillä. Myös Riipisen (2018, 46-47) tutkimuksessa ihmiset pitivät turvetuotantoa suurimpana syyllisenä vesien pilaantumiseen. Kokemusta turpeennoston ongelmallisuudesta ilmentää myös se, että mitä enemmän ollaan eri mieltä väitteen "Veden laatu on moitteetonta" kanssa, sitä enemmän katsotaan turvetuotannon vaikuttaneen vesien huononemiseen $(\mathrm{r}=.45, \mathrm{p}=.000)$. Muista vesien tilaan vaikuttavista tekijöistä (ks. kuvio 2) vain metsien ja soiden ojitus korreloi veden laadun moitteettomuuden kanssa tilastollisesti merkitsevästi $(\mathrm{r}=.15, \mathrm{p}=.006)$. Tätä yleisarviota täsmentävät taulukossa 2 esitettävät korrelaatiotiedot. Ne tuovat esiin tekijät, jotka vastaajat vahvimmin yhdistävät turvetuotannon ongelmallisuuteen.

Taulukon korrelaatiot ovat korkeita eli kokemus tekijöiden yhteydestä turpeennoston vesiä huonontavaan vaikutukseen on selvä. Korkein yhteys koskee turvepölyä. Tarkasteltuja yhteyksiä hieman lievempiä, mutta suhteellisen vahvaa yhteyttä ilmaisevia korrelaatioita vesien huononemiseen esiintyi myös väitteisiin "Leväkasvusto on lisääntynyt" $(r=.33)$ ja "Vesi haisee epämiellyttävältä" $(r=.27)$.

Taulukko 2. Turpeennoston vesiä huonontavat ilmentymät, korrelaatiot

Table 2. Manifestations of deterioration of waters due to peat harvesting, correlations

\begin{tabular}{|l|l|}
\hline VÄITE & Turpeennoston vesiä huonontava vaikutus \\
\hline Vesien pinnalla on näkynyt turvepölyä & $\mathrm{r}=.48$ \\
\hline Vesien pinnalla on kellunut turvelauttoja & $\mathrm{r}=.42$ \\
\hline Rannat/uimarannat ovat liettyneet & $\mathrm{r}=.41$ \\
\hline Vedet ovat tummempia kuin ennen & $\mathrm{r}=.39$ \\
\hline Ojista ja puroista valuu vesiä likaavaa turvetta ja mutaa & $\mathrm{r}=.39$ \\
\hline Avannoista ja railoista nousee mutaista vettä jäälle & $\mathrm{r}=.37$ \\
\hline
\end{tabular}

Spearmanin järjetyskorrelaatiokerroin $r$

Taulukkoon 2 on otettu yhteydet, joissa vastaajien mielestä selvimmin esiintyy turpeennoston vesiä huonontava vaikutus. Kaikkien yhteyksien osalta korrelaatio on erittäin merkitsevä $(p=.000)$. (Korrelaatiot: $R$, liite Kyselylomake, kysymys $5 / 3$, turvetuotanto, ja kysymys 9, väitteet I-49). 
Muutosten koetaan huonontavan vesistön virkistyskäyttöä. Väite "Veden laadusta ei ole haittaa vesien ja rantojen virkistyskäytölle" sai negatiivisen korrelaatioarvon $r=-.35$. Taulukon 3 tiedot selvittävät tarkemmin, mihin virkistyskäytön muotoihin turpeennoston koetaan olevan vahvimmin yhteydessä.

Asiaa tarkennetaan seuraavassa eriyttämällä tarkasteluun turvekriittisten ryhmä, eli ne, jotka valitsivat turpeennoston ongelmallisuuden arvioinnissa kärkevimmän vaihtoehdon (kuvio 2 kohdassa turvetuotanto, 56,9 prosenttia, $\mathrm{n}=209$ ). Voidaan siis olettaa, että kokemus toteutuneesta kehityksestä on määrittelyjen taustalla. Eniten näitä turvekriittisiä on kunnissa, joissa turpeennosto on yleisintä. Taulukon 4 prosenttiosuudet ilmaisevat, mihin virkistyskäytön osa-alueisiin nämä turvekriittiset kokevat vahvimmat kielteiset yhteydet.

Avoimissa vastauksissa kriittistä suhtautumista turvetuotantoon kuvattiin sanomalla, että "turve on suurin syntipukki" ja että "harmittaa vietävästi turvetuotanto, kun se pilaa vedet eikä niitä valvo kukaan". (R, 39)

\section{Asukkaiden suhtautuminen turvetuotantoon}

Taulukko 3. Turvetuotannon koettu yhteys vesien virkistyskäyttöön, korrelaatiot

Table 3. Perceived connections between peat harvesting and recreational use of waters, correlations

\begin{tabular}{|l|l|}
\hline VÄITE & Turvetuotanto vesien huonontajana \\
\hline Veneiden pohjat likaantuvat & $\mathrm{r}=.43$ \\
\hline Uiminen aiheuttaa iho-oireita ja iholle tarttuu mutaa & $\mathrm{r}=.43$ \\
\hline Maiseman virkistysarvo on vähentynyt & $\mathrm{r}=.41$ \\
\hline Kalastusvälineisiin kertyy lietettä & $\mathrm{r}=.38$ \\
\hline Uiminen on vähentynyt veden likaantumisen vuoksi & $\mathrm{r}=.37$ \\
\hline Kalastaminen on vähentynyt vesistömuutosten vuoksi & $\mathrm{r}=.33$ \\
\hline $\begin{array}{l}\text { Vesissä ei voi pestä mattoja tai muuta pyykkiä veden } \\
\text { likaantumisen vuoksi }\end{array}$ & $\mathrm{r}=.33$ \\
\hline
\end{tabular}

Spermanin järjestyskorrelaatiokerroin $r$

Taulukkoon on otettu vähintään $r=.30$ vahvuiset korrelaatiot. Kaikki yhteydet ovat tilastollisesti erittäin merkitseviä $(p=.000)$.

Taulukko 4. Virkistyskäytön heikentyminen: "turvekriittiset” $(n=197-210)$

Table 4. Deterioration of the recreational use of waters, by "peat critics" $(n=197-210)$

\begin{tabular}{|l|l|}
\hline & $\begin{array}{l}\text { Vähentynyt huomattavasti tai jonkin verran: } \\
\text { "Turvekriittiset” (\%) }\end{array}$ \\
\hline Uiminen lähivesistössä & 59,9 \\
\hline Pyykinpesu veden äärellä & 56,9 \\
\hline Luonnonveden käyttö pesuvetenä & 50,5 \\
\hline Peseytymisen tarve uinnin jälkeen lisääntynyt & 48,1 \\
\hline Luonnonveden käyttö löylyvetenä & 44,2 \\
\hline Kalastus & 43,6 \\
\hline Lähivesistöstä pyydetyn kalan syönti & 40,9 \\
\hline Veneily & 33,9 \\
\hline Liikkuminen ja ajanvietto vesistön äärellä & 31,4 \\
\hline
\end{tabular}

Listauksessa ylimpänä olevien vaikutusten osalta turvekriittisten ero muihin vastanneisiin oli suurin ( $R$, 53), mikä viittaa kokemukseen turvetuotannon huomattavasta roolista juuri näitä vaikutuksia koskevissa arvioissa. Turvekriittiset tarkoittavat tässä ja muualla niitä, jotka valitsivat kärkevimmän vaihtoehdon "erittäin paljon" kysymykseen turvetuotannon vaikutuksesta vesiä huonontavana tekijänä (ks. kuvio 2). 
Haittojen tunnistaminen johtaa turpeennostoon kohdistuviin toiveisiin ja vaatimuksiin. Tässä tulemme sosiaalisen toimiluvan keskeiselle alueelle.

Suurin osa kysymykseen vastanneista katsoo erittäin tärkeäksi turvetuotannon valvonnan tehostamisen, "turvekriittisistä" peräti 82 prosenttia (ks. taulukko 5). Myös jyrkkä vaatimus vesistön tilaan vaikuttavien lupaehtojen yleisestä kiristämisestä on laajaa reitin asujaimiston keskuudessa ja se voidaan kyselytiedon valossa tulkita kohdistuvan paljolti, joskaan ei pelkästään, turvetuotantoon. Myös maatalouden päästöt (peltojen lannoitus) ja metsien ja soiden ojitus koettiin laajalti ongelmia tuottavina (kuvio 2).

Hankkeen sosiaalista toimilupaa asujaimiston keskuudessa eivät kuitenkaan märitä vain haitat ja ongelmat, vaan myös hankkeen mahdolliset myönteiset puolet (Moffat \& Shang 2014). Etujen ja haittojen keskinäinen punnitseminen tuottaa lopullisen toimilupa-johtopäätöksen. Turvetuotannon keskeisiä paikallisia hyötyjä ovat verotulot, paikallinen energiantuotanto ja työllisyysvaikutukset. Yleisesti ottaen ne voivat olla merkittäviä etuja muuttotappioista kärsivillä seuduilla, jollaista reittialue edustaa. Kyselymme antaa tietoa kahdesta jälkimmäisestä tekijästä (ks. kuvio 5).

Kummankin väitteen kohdalla eri mieltä vastanneiden osuus on moninkertainen samaa mieltä vastanneisiin nähden. Saarijärven reitin varren asujaimiston mielestä turpeen noston tuottamat haitat ovat vahvasti hyötyjä suuremmat, ja näin arvioidaan olevan erityisesti keskeisimmillä turvetuotantoalueilla.

Molemmissa väitteissä kysymyksen muotoilu koskee turpeen tuotannon lisäystä, eikä niissä siis tarkkaan ottaen oteta kantaa kyselyhetkellä vallinneeseen tilanteeseen. Sen sijaan nykyiseen kokonaistilanteeseen kantaa ottaa väite "Turpeen nosto tulisi lopettaa kokonaan". Sen kohdalla ollaan turvetuotannon sosiaalisen toimiluvan ytimessä. Väite on erittäin voimakas muotoilu ja sen osalta vastaajat joutuvat suoraan punnitsemaan haittoja ja hyötyjä. Tarkastelemme kannanmäärityksiä tutkimuskunnittain (ks. kuvio 6).

Vähintään jokseenkin samaa mieltä väitteen kanssa kaikista vastanneista oli lähes puolet eli 48 prosenttia ja turvekriittisistä 72 prosenttia. Kymmenes vastanneista oli täysin eri mieltä väitteen sisällön kanssa.

Taulukko 5. Sääntelyvaatimukset

Table 5. Regulatory requirements from local residents

\begin{tabular}{|l|l|l|l|l|}
\hline Kärkevimmän vaihtoehdon (täysin samaa mieltä) valinneiden osuudet \% \\
\hline & Kaikki & $\mathrm{n}$ & $\%$ & $\mathrm{n}$ \\
\cline { 2 - 6 } & $\%$ & 429 & 81,9 & 172 \\
\hline Turvetuotannon valvontaa tulisi tehostaa & 55,6 & 435 & 65,0 & 134 \\
\hline $\begin{array}{l}\text { Vesistöjen tilaan vaikuttavien toimien } \\
\text { lupaehtoja tulee kiristää }\end{array}$ & 45,9 & & & \\
\hline
\end{tabular}



Kuvio 5. Turvetuotannon koetut hyödyt

Figure 5. Perceived benefits of peat harvesting 


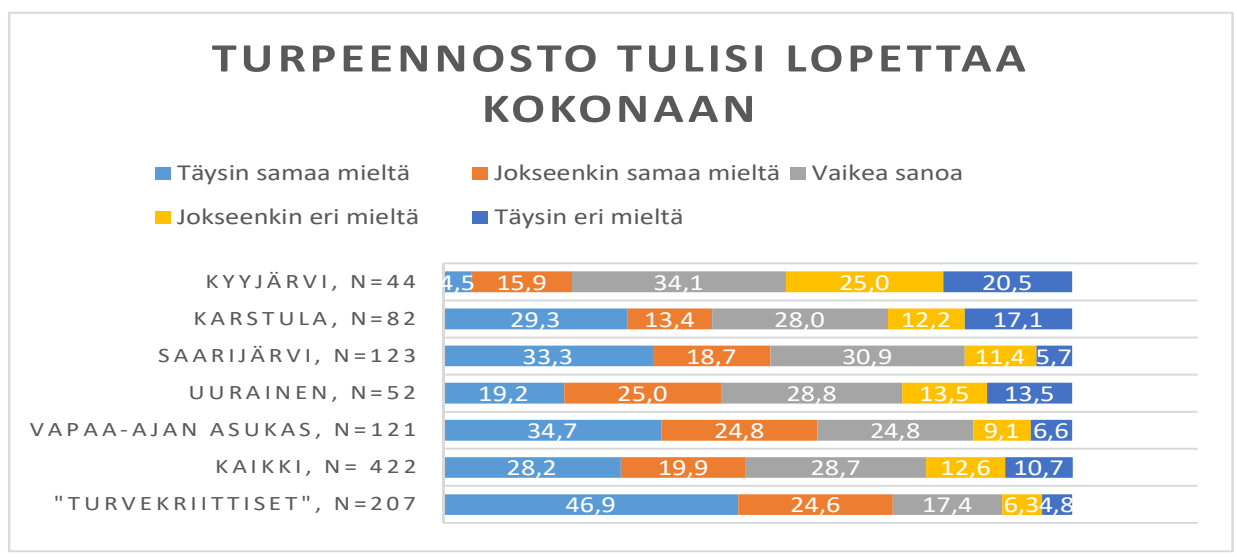

Kuvio 6. Kannanotot väitteeseen "Turpeennosto tulisi lopettaa kokonaan" kunnittain (\%)

Figure 6. Responses of local residents to the statement "Peat harvesting should be stopped completely", by municipality (\%)

Näin vahva hyväksyntä kärjekkäälle väitteelle ilmentää asujaimiston suuren osan luottamuksen vakavaa horjumista turpeennostoon ja hyväksynnän epäämistä siltä. Tällainen yleinen kannanmääritys viittaa siihen, että epäluottamus ei kohdistu vain yksittäisiin tuotantokohteisiin, vaan turpeennostoon laajalti Saarijärven reitin alueella ja mahdollisesti valtakunnallisesti. Kuitenkin myös keskimmäinen vaihtoehto kolme saa paljon merkintöjä (29 prosenttia vastanneista), mikä on tulkittavissa monen vastaajan haluttomuudeksi tai vaikeudeksi ottaa kantaa voimakkaaseen väitteeseen, onhan turpeen nostosta myös paikallisia hyötyjä. Luultavasti osa kysymykseen vastaamatta jättäneistä $(n=49)$ kokee samoin.

Turpeennoston ongelmat suurimpina kokeneiden turvekriittisten ryhmässä oli pieni vähemmistö ( $\mathrm{n}=23)$ niitä, jotka ottivat negatiivisen kannan väitteeseen. He siis pitävät mahdollisena turpeen ongelmatonta tuotantoa joissain tapauksissa, mittakaavassa tai olosuhteissa.

Kuntakohtaisessa tarkastelussa on havaittavissa selviä eroja. Ainoana kunnista Kyyjärvellä eri mieltä väitteen kanssa on hyväksyvää kantaa suurempi osa. Työllisyysnäkökohdat näyttäisivät siellä selittävän osaltaan tätä, sillä muita kuntia suurempi osa kyyjärveläisistä ilmoitti hyväksyvänsä turvetuotannon lisäämisen työllisyysvaikutusten vuoksi. Kuitenkin heistäkin alle kolmannes oli tätä mieltä, jota vastoin 40 prosenttia vastasi, että turvetuotantoa ei tulisi lisätä työllisyysnäkökohtien vuoksi. Karstulassa vallitsee vahva polarisaatio: ärripäät saavat runsaasti kannatusta, täysin samaa mieltä -ääripää tosin selkeästi suuremman. Saarijärven sekä vapaa-ajan asukkaista kolmannes esittää vahvan puollon vaatimukselle turpeennoston lopettamisesta, kun vahvasti vastakkaista mieltä on pieni vähemmistö. Aineisto ei anna mahdollisuutta tutkia yksityiskohtaisemmin erojen syitä. Myös niin kyyjärveläisten kuin uuraislaistenkin vastanneiden määrä on siksi pieni, että tuloksia heidän osaltaan voidaan pitää suuntaa antavina tai jopa epävarmoina yleistettäviksi kunnan asukkaisiin.

Lopuksi täsmennämme arkikokemuksen asemaa tarkasteltujen vesistöongelmien hahmottamisessa. Kokemus syntyy paljolti intressiperustaisesti aistihavaintojen, keskustelujen ja muun saatavilla olevien tietolähteiden vuorovaikutuksessa. Se sisältää myös historiallisen ulottuvuuden. Tutkimuksen tapauksessa kokemuksen keskeiseksi intressiksi osoittautui vesistöjen virkistyskäyttö.

Kokemuksen näkökulmasta on luonnollista, että kyselyn avoimissa vastauksissa etusijalle nousivat kiintoaines- ja humuspäästöt. Niiden vaikutukset ovat helpoimmin aistein havaittavissa vesien tummentumisena ja näkösyvyyden heikentymisenä, ja ne kohdistuvat suoraan virkistyskäyttöön. Turvepöly saattaa tuulten mukana kulkeutua kilometrien pähän aiheuttaen haittaa virkistyskäytölle. Turvepöly synnyttää veden pinnalle epämiellyttävän kalvon, ja se nousee humuksen ja kiintoaineksen muodossa talvella esiin ruskeana mössönä jään halkeamista. Turvetuotannon vaikutus juuri kiintoaineksen ja humuksen muodossa voi olla virkistyskäyttöön merkittävä etenkin alueilla, joilla niiden luonnollinen lähtötaso on korkea.

Asukkaat kertoivat omista havainnoistaan muun muassa seuraavasti: "Turvepöly laskeutun tuulen mukana isolle alueelle". "Järvien railoista purswva turvemoska on lisääntynyt". "Nokea ja turvepöbyä veden pinnalla poudalla". 
Kokemuksen näkökulmasta turpeennosto näkyvänä välittömänä päästölähteenä ja koettuna uhkana voi saada osakseen myös syytöksiä, joihin se ei yksin tai edes pääasiallisesti ole syypää. Tehometsätalouden huippuvuosikymmeninä 1960- ja 1970-luvuilla metsien laajamittaiset lannoitukset muun muassa Keski-Suomessa, sekä kauan sitten tehdyt metsien ja soiden massiiviset ojitukset tuottavat edelleen kumuloitumisefektin ravinteiden (fosfori ja typpi) kulkeutumiseen vesistöihin ja vaikuttavat niiden rehevöitymiseen. Lannoitteet ovat pakkautuneet metsä- ja suomaaperään ja yhä vuosien päästä rehevöittävät vesistöjä. Voidaan myös kysyä, millainen on humuksen, kiintoaineksen ja sekä fosforin ja typen yhteisvaikutus.

Ojitus antaa osaltaan väylän maa- ja metsätalouden rehevöittäville päästöille. Niihin yhdistyneenä humus ja kiintoaine tuottavat veneiden pohjien ja verkkojen limoittumista. Vaikutus on kestänyt vuosikymmeniä, ja kumuloitumisen seurauksena on tultu sietotason ylärajalle. Mitta pitkään jatkuneeseen vesien huononemiseen on tullut täyteen, ja siihen vaikuttavat uudet hankkeet joutuvat arvostelun kohteeksi. On syytä huomata, että soiden ja metsien ojitus sekä maatalouden lannoitepäästöt saivat paljon huomiota osakseen myös tässä tutkimuksessa (kuvio 2). Toiseksi, viranomaisten laatuluokitusten mukaan erinomaisessa kunnossa olevat vesialueet reitin alueella eivät sijaitse turvetuotantoseuduilla.

\section{Johtopäätökset}

\section{Onko turvetuotannolla sosiaalista toimilupaa?}

Saarijärven reitin turvetuotannon hankkeiden vaikutusalueella asuu lähes 20000 ihmistä. Kyselytutkimuksemme on ensimmäinen yritys kartoittaa yleistykseen pyrkivällä otteella asukkaiden näkökantoja alueella tapahtuvan turpeennoston hyväksyttävyydestä. Tutkimusotteemme ja aineistomme täyttävät sosiaalisen toimiluvan arvioinnin edellytykset paikallisella tasolla.

Sosiaalisen toimiluvan keskeinen kysymys koskee Moffat'n ja Shangin (2014) mukaan bankkeeen vaikutuksia ybteisön infrastruktuurïn ja byväksyntää asianosaisten määrittämänä. Asianosaisten ydinryhmän muodostaa hankkeen vaikutusten alainen asujaimisto. Kysely tuotti monipuolista aineistoa hyväksyntään vaikuttavista tausta- ja motiivitekijöistä sekä turpeennoston haitoista ja hyödyistä asukkaiden kokemana. Tulosten perusteella voidaan vastata sosiaalisen toimiluvan ydinkysymykseen.

Saarijärven reitin varren asukkaiden ja vapaa-ajan asukkaiden kannanmääritykset turvekysymyksessä nousevat vahvasti vesistön virkistyskäytön perustalta. Nämä arviot ovat laajalti kielteisiä. Turpeen nostaminen koettiin suurimmaksi vesistöjä pilaavaksi tekijäksi. Kokemus vesistön laadun heikkenemisestä peittoaa painoarvoltaan selvästi sellaiset hyödyt kuin turvetuotannon paikalliset työllisyysvaikutukset ja energian tuotanto. Vastaajajoukosta monet sanovat myös paikkakunnan imagon kärsineen vesien tilan heikentymisestä. Ulkopuolisille, kuten matkailijoille tai potentiaalisille vapaa-ajan asukkaille ei enää ole monen mielestä mahdollista mainostaa paikkakuntaa puhtaiden vesien seutuna (R, 49).

Kielteisimmin turpeen nostoon suhtaudutaan Karstulassa, jossa turvetta nostetaan alueen kunnista eniten, mutta lähes yhtä kielteisesti myös Saarijärvellä, jonka kohdalla turvetuotanto keskittyy vahvasti kaupungin länsipuolelle. Tutkimuksen kunnista vähimmin kritiikkiä esiintyy Uuraisilla, missä turvetta nostetaan vähiten tutkimuskunnista. Aineisto ei mahdollista järvikohtaista eikä myöskään yrityskohtaista tarkastelua.

Tutkimus antaa sosiaalisen toimiluvan ydinkysymykseen kielteisen vastauksen. Moffat'n ja Shangin (2014) toinen ja kolmas sosiaalisen toimiluvan elementti koskevat hanketta ajavan yrityksen laadullista ja määrällistä kanssakäymistä kohdeyhteisön kanssa. Tätä koskevaa aineistoa tutkimuksessa hankittiin vähän. Kuitenkin kun kysyttiin, mistä asukkaat ovat saaneet tietoa vesistöreitin tilasta ja tilaan liittyvistä kysymyksistä, kymmenen tietolähteen vertailussa vesiin vaikuttavat yritykeset saivat vähäisimmät maininnat pyydettäessä nimeämään kaksi tärkeintä tietolähdettä (R, kuvio 19, s. 51). Vesistön varren asukkaiden ja kansalaisyhdistysten taholta on usein esitetty turveyritysten kritiikkiä ja yritysten puolelta tuo kritiikki on usein suoraviivaisesti kiistetty. Paitsi että kanssakäyminen on ollut vähäistä, on se koettu laadullisesti heikoksi luottamuspulan leimaamaamaksi kiistelyksi. Asukkailla kanssakäymistä on lähinnä vain hallinnollisten viranomaisorganisaatioiden kanssa.

Neljättä elementtiä, yrityksen toiminnallista reiluntta koskevaa aineiston hankintaa tutkimukseen ei varsinaisesti sisältynyt eikä kysely tuottanut tietoa myöskään turvetuotantoyritysten mahdollisista eroista. 
Kansalaisyhdistykset ovat kuitenkin arvostelleet turveyrittäjien tekemiä kuormitusmittauksia ja pitäneet niitä epäluotettavina (Pelastetaan Reittivedet -yhdistys 2017).

Kaikki elementit vaikuttavat asujaimiston luottamuksen tilaan yritykseen nähden. Tulokset ilmentävät vakavaa ja laajaa luottamuspulaa turvetuotannon yrityksiin. Kyselyyn vastanneista 78 prosenttia vaati turvetuottajien tiukempaa valvontaa ja 70 prosenttia lupaehtojen kiristämistä. Suuri osa kyselyyn vastanneista oli sitä mieltä, että turpeennosto tulisi lopettaa kokonaan. Luottamuspulaan on luultavasti vaikuttanut yleiseen tietämykseen tulleet tapaukset ongelmista yritysten itsensä tekemissä päästömittauksissa.

\section{Sosiaalisen toimiluvan menetys}

Otsikkomme muotoilu "sosiaalisen toimiluvan menetys" viittaa muutokseen, siihen, että turvetuotannolla on joskus aikaisemmin ollut paikallisen väestön hyväksyntä. Vaikka tästä ei ole kattavaa tutkimustietoa Saarijärven reitiltä tai muualtakaan, näkemys on perusteltu muutamien tutkimuskirjallisuudessa esiintyvien huomioiden valossa. Albrecht $(2015,161)$ huomauttaa, että turvetuotannon käynnistymisvaiheessa eräässä Keski-Pohjanmaan hankkeessa paikallisten asukkaiden mielenkiinto hankkeeseen oli vähäinen. Syrjämäen $(2013,63)$ haastateltavat puolestaan kertoivat omakohtaisista kokemuksistaan ja ajatuksistaan niiltä ajoilta, kun turvetuotanto Suomessa aloitettiin. Kerrottiin, että ihmiset ovat parhaan silloisen tiedon ja uskon varassa tehneet päätöksiä, jotta kotimainen energiantuotanto pystyttäisiin takaamaan. Tuotannon ympäristövaikutuksia ja muita negatiivisia vaikutuksia ei silloin osattu ajatella eikä varsinkaan vesistöihin kohdistuvia haittavaikutuksia huomioitu lainkaan. Vallitsi epätietoisuuden tila, jossa lupaukset paikallisista eduista - työllisyys- ja paikalliset talousvaikutukset - määrittelivät asukkaiden suhtautumista turvetuotantoon. Valtakunnalliset ja paikalliset viranomaiset puolustivat turpeennostoa öljykriisin jälkimainingeissa, kuten myös monet tunnetut poliitikot silloin ja myös myöhemmin. Jos epäluuloa esiintyi, ei se kokemuksen puuttuessa kehittynyt vastustukseksi.

Jos paikallinen asujaimisto suhtautui alussa turpeennostoon ainakin useimmiten passiivisesti ja odottavasti, luonnonsuojelujärjestöt - Suomen luonnonsuojeluliitto etunenässä - sen sijaan ovat esittäneet kritiikkiä tehometsätaloutta ja soiden ojituksia kohtaan jo varhain. Teemat olivat vahvasti esillä esimerkiksi Suomen luonto -lehden metsänumerossa vuonna 1970. Turpeennosto on soiden suojeluarvon näkökulmasta ollut luonnonsuojelijoiden valvovan silmän ja kritiikin kohteena erityisesti turvepolitiikan muutoksen jälkeisellä kaudella. Vuoden 1981 Suuren Venenevan tapaus (ks. Lindholm \& Heikkilä 2008, 78) näyttää olleen merkittävä sysäys. Oulun lähellä sijaitseva Suuri Veneneva oli sisällytetty valtakunnalliseen soidensuojeluohjelmaan. Silti Turveruukki Oy aloitti siellä turvetuotantoon tähtäävät ojitukset. Tapauksen saama julkisuus johti siihen, että kaikki eduskuntapuolueet allekirjoittivat yhteisen vetoomuksen suon säilyttämisen puolesta. Turveruukki perääntyi suunnitelmastaan. Tapauksen jälkeen turveyhtiöt ovat olleet varovaisia suojelusoihin kajoamisessa.

\section{Sosiaalisen toimiluvan merkitys turpeen nostoa koskevassa päätöksenteossa}

Ympäristöpoliittisesti keskeinen kysymys koskee asujaimiston näkökantojen legitimiteettiä päätöksenteossa. Turpeennostoa koskevassa virallisessa lupamenettelyssä näkökulman legitimiteetti on nykyisellään kyseenalainen. Turvetuotannon toimilupajärjestelmä on sellainen, että tuottajat eivät tarvitse paikallista sosiaalista hyväksyntää ja toimilupaa. Ympäristölainsäädännön perusteella ratkaisevaa on ympäristölupamenettely ja luvanmukaisilla menetelmillä osoitetut vaikutukset veden laatuun. Jos asukkaat haluavat vastustaa turpeen nostoon oikeuttavia lupia, heidän on käytettävä lainsäädännön mukaista muistutus- ja valitusmenettelyä eli hyväksynnän testaus tulee vasta päätöksentekoprosessin lopussa tai jälkeen. Vesistön tilaan ja asukkaiden kokemukseen ovat vaikuttaneet siten myös suomalaisen paikallisen päätöksenteon rakenteet ja kulttuuri - vahva viranomaiskeskeisyys. Jopa kuntien itsensä asema päätöksenteossa on toissijainen muihin viranomaisiin, kuten ely-keskuksiin nähden. Viranomaiskeskeinen käytäntö on merkinnyt, että turvetuottajien ei ole tarvinnut opetella vuoropuhelua asukkaiden ja ympäristöaktivistien kanssa. Kanssakäymisestä ei tullut keskustelua, vaan epäluulon leimaamaa kiistelyä. Osaltaan haitankärsijöiden vuosikymmenten kokemus sivuutetuiksi tulemisesta on syövyttänyt luottamuksen minimiin turpeentuottajiin. 
Vallinnut lupakäytäntö on johtanut jatkuviin ja toistuviin konflikteihin turpeentuottajien ja hankkeiden vaikutusalaisten vesistöjen varsien asukkaiden kesken. Kokemus turpeennoston haitoista on monissa tapauksissa ollut ristiriidassa lupamenettelyn pohjana olevien päästölaskelmien kanssa.

Sosiaalisen toimiluvan mukainen ajattelu tähdentää, että hankkeiden hyväksyttävyys tulisi selvittää suunnittelu- ja päätöksentekoprosessin aikana myös hankeosapuolen ja paikallisten asukkaiden välisessä välittömässä vuorovaikutuksessa. Lisäksi tulisi sopia vuorovaikutuksesta hankkeiden kestäessä, sillä niiden ympäristö- ja sosiaalisia vaikutuksia on mahdotonta selvittää pitävästi etukäteen. Siten pystyttäisiin viivytyksettä reagoimaan ennakoimattomiin haittoihin ja ongelmiin. Vuorovaikutus ehkäisisi väärinkäytösten ja välinpitämättömän toiminnan mahdollisuutta, koska kanssakäymiseen itseensä sisältyy aina myös luonnollisen kontrollin elementti. Kanssakäymisen luonnollinen kontrolli vahvistaa luottamusta ja ehkäisee väärinkäytöksiä. Hankkeen jatkamisen uhkana tulisi olla virallisen toimiluvan menetys niissä tapauksissa, joissa haitat ovat olennaisesti ennakoituja suuremmat. Menettely tarkoittaisi siirtymistä sosiaalisen toimiluvan tarkoittamaan toimintamalliin. Se tuntuisi soveltuvan hyvin turpeennoston kaltaisiin hankkeisiin, joissa sekä ennakoidut hyödyt että haitat ovat suuressa määrin paikallisia.

Tutkimuksen kohteena oleva vesireitti ei ole turvehaittojen osalta ainutlaatuinen vaan turvekiistojen esiintymisistä voi päätellä, että samanlaisia tilanteenmäärittelyjä on muuallakin. Vaatisi kuitenkin laajemman tutkimuksen, jotta ilmiön yleisyydestä voitaisiin sanoa tarkempaa.

Tulokset viittaavat myös siihen, että suhtautumisessa turvetuotantoon on elämäntavasta ja arvoista johtuvia eroja. Muita kriittisempiä ovat ne ihmiset, joilla on kiinteä suhde luontoympäristöön ja jotka harrastavat luontoaktiviteettejä. Myös ihmisten luontosuhteen ja ympäristöhaittojen välisestä yhteydestä kaivataan lisätutkimuksia.

Tutkimuksemme osoittaa, että sosiaalisen toimiluvan käsite soveltuu turvetuotannon ja paikallisen asukkaiden suhteen sekä turvetuotannon paikallisen hyväksyttävyyden analysointiin. Turvetuottajien ja paikallisten asukkaiden välinen vuorovaikutus on vähäistä. Tästä herää kysymys, onko paikallisten ihmisten hyväksyntä tärkeä asia turvetuottajille vai katsovatko he, että turpeen nostoa koskevan lupaprosessin yhteydessä käytävä vuoropuhelua lupaviranomaisten kanssa on riittävä. Omassa tiedottamisessaan turvetuottajat korostavat, että he täyttävät toiminnassaan lupaehdoissa asetetut vaatimukset, jotka takaavat sen, että vesistöön pääsee vain puhdasta vettä. Juridinen toimilupa (ympäristölupa) ja sosiaalinen toimilupa näyttävät olevan eri asioita ja pahimmassa tapauksessa ristiriidassa keskenään. Joka tapauksessa asukkaiden kokemuksista voi päätellä, että he eivät koe pystyvänsä vaikuttamaan riittävästi lupaprosesseihin. Tähän viittaa myös se, että turvetuotannon mahdollistavista lupapäätöksistä Pelastetaan reittivedet -yhdistyksen keräämien tietojen mukaan melkeinpä aina valitetaan (Pelastetaan reittivedet -yhdistys 2017).

Sosiaalisen toimiluvan käsitteen esittelyn yhteydessä toimme esille, minkälaisia tasoja, asteita ja ulottuvuuksia käsitteellä on. Tarkastelua voitaisiin syventää ottamalla sosiaalisen toimiluvan käsite tutkimuksen lähtökohdaksi ja suunnitella empiirisen aineiston hankinta siten, että käsitteen eri ulottuvuudet tulisivat kattavammin testatuiksi ja hyödynnetyksi. Siten voitaisiin lisätä ymmärrystä kiistasta, joka selvästi vaivaa paikallisia asukkaita.

\section{Kiitokset}

Haluamme kiittää kahta anonyymiä arvioijaa rakentavista kommenteista. Tutkimuksen rahoituksesta kiitämme Keski-Suomen Liittoa, Saarijärven kaupunkia, Karstulan ja Uuraisten kuntia sekä Suomen Akatemian yhteydessä toimivan Strategisen tutkimuksen neuvoston rahoittamaa CORE-hanketta (313013, 313015).

\section{Lähteet}

Albrecht, E. (2015) Energiaa vai luonnonrauhaa? Puolesta ja vastaan argumentointi paikallisessa turvekonfliktissa KeskiPohjanmaalla. Terra 127(4) 157-168.

Bice, S. \& Moffat, K. (2014) Social licence to operate and impact assessment. Impact Assessment and Project Appraisal 32(4) 257-262. Boutilier, R., G. (2014) Frequently asked questions about the social licence to operate. Impact Assessment and Project Appraisal 
32(4) 263-272.

Flyktman, M. (2009) Energia- ja ympäristöturpeen kysyntä ja tarjonta vuoteen 2020 mennessä - Toinen päivitys. VTT, TutkimusraporttiVTT_R-07128-09.41, Helsinki.

Hall, N., Lacey, J., Carr-Cornish, S. \& Dowd, A. (2015) Social licence to operate; understanding how a concept has been translated into practice in energy industries. Journal of Cleaner Production 86, 301-310.

Högmander, P. \& Pehkonen, T. (toim.) (2014). Turvetuotannon ja metsätalouden vesiensuojelun kehittäminen. TASO-hankkeen loppuraportti. URN:ISBN:978-952-314-063-9.

Layder, D. (1998) Sociological Practice. Linking Theory and Practice. Sage, London.

Leinonen, A. (toim.) (2010) Turpeen tuotanto ja käyttö. Yhteenveto selvityksistä. VTT. Edita Prima, Helsinki.

Lilleberg, T. (2015).Turvekiistan anatomia. Sukellus Suomen julkiseen turvekeskusteluun. ympäristötieteen pro gradu-tutkielma, Helsingin yliopisto. https://helda.helsinki.fi/bitstream/handle/10138/155120/turvekii.pdf?sequence=1

Lindholm, T. \& Heikkilä, R. (2008) Suuren Venenevan tapaus säikäytti turveyhtiöt. Teoksessa Telkänranta, H., Simola, H. \& Ajomaa H. (toim.) Laulujoutsenen perintö: Suomalaisen ympäristöliikkeeen taival, 78. Suomen luonnonsuojeluliitto. WSOY, Helsinki.

Litmanen, T., Jartti, T. \& Rantala, E. (2016) Refining the preconditions of a social licence to operate (SLO): reflections on citizens' attitudes towards to mining in two mining regions in Finland. The Extractive Industries and Society, 3(3) $782-792$.

Moffat, K. \& Zhang, A. (2014) The paths to social licence to operate: an integrative model explaining community acceptance of mining. Resources Policy 39 61-70. https://doi.org/10.1016/j.resourpol.2013.11.003

Mononen, T. \& Suopajärvi, L. (toim.) (2016) Kaivos suomalaisessa ybteiskunnassa. Lapin yliopistokustannus, Rovaniemi.

Mustonen, Tero (2013) Oral histories as a baseline of a landscape restoration - Co-management and watershed knowledge in Jukajoki River. Fennia 191(2) 76-91.

Möttönen, S., Konttinen, E. \& Salo, M. (2016) Ei vettä rantaa rakkaampaa - Asukkaiden arvioita Saarijärven reitin tilasta ja muutoksista. Keski-Suomen liitto. Sarja B 203. ISBN 978-951-594-487-0, sähköinen. Keski-Suomen liitto, Jyväskylä.

Niemi, O. (toim.) (2013) Tämänkö olemme menettämässä? Pelastetaan reittivedet -raportti. 26.4.2017. http://reittivedet.fi/ wp-content/uploads/2013/05/Raportti_ONiemi.pdf. 5.6.2017

Pelastetaan reittivedet -yhdistys (2017) Kirjoitukset. www.reittivedet.fi/kirjoitukset. 5.6.2017.

Peltonen, L. (2016) Kaivostoiminnan legitimiteetin muotoutuminen: paikallisesta hyväksyttävyydestä yhteiskuntakelpoisuuden ymmärtämiseen. Teoksessa Mononen, T. \& Suopajärvi, L. (toim.) Kaivos suomalaisessa yhteiskunnassa, 135-159. Lapin yliopistokustannus, Rovaniemi.

Riipinen, P. (2018) Halukkuus osallistua vesienhoitoon Saarijärven vesireitin alueella. Kyselytutkimus Saarijärven vesireitin asukkaille. Opinnäytetyö. Jyväskylän ammattikorkeakoulu. http://urn.fi/URN:NBN:fi:amk-201802132362

Ruuskanen, E. (2010) Suosta voimaa ja lämpöä: Turve Suomen energiapolitiikassa 1940-2010. Vapo Oy, Jyväskylä.

Sairinen, R. (2015) Sosiaalisen toimiluvan käsite ja paikallinen hallinta. Esitelmä konferenssissa "Kuopasta kansalle kaivosteollisuuden hyväksyntä ja paikallinen hallinta" 16.-17.3.2015. tiedekeskus Heureka, Vantaa. https://www2.uef. fi/documents/1207803/2714973/Sairinen+17-3-2015+SLO+Heureka+konferenssi+b.pdf/d55ed89f-c679-40ee-8144d3fa8d57028e. 31.1.2018.

Salo, M. (2015) Energiakäänne : Saksan ja Suomen energiapoliittiset valinnat. Vihreä Sivistysliitto ry. Hämeen Kirjapaino Oy, Helsinki.

Suomen luonnonsuojeluliitto (2013) SLL: Turvepäästöt lasketaan väärin. SLL tiedote 2.9.2013. http://www.sll.fi/ajankohtaista/ tiedotteet/2013/sll-turvepaastot-lasketaan-vaarin. 5.6.2017.

Suomen ympäristökeskus (2017) Pintavesien luokittelun periaatteet. http://www.ymparisto.fi/fi-FI/Vesi/Pintavesien_tila/ Pintavesien_luokittelu. 5.6.2017

Suomen ympäristökeskus (2015) Vesikartta. Vesien ekologinen tila. http://paikkatieto.ymparisto.fi/vesikarttaviewers/ Html5Viewer_2_5_2/Index.html?configBase=http://paikkatieto.ymparisto.fi/Geocortex/Essentials/REST/sites / VesikarttaKansa/viewers/VesikarttaHTML525/virtualdirectory/Resources/Config/Default. 13.5.2017.

Suopajärvi, L. \& Sairinen, R. (2016) Sosiaalisten vaikutusten arviointi kaivostoiminnassa. Teoksessa Mononen, T. \& Suopajärvi, L. (toim.) (2016) Kaivos suomalaisessa yhteiskunnassa,38-56. Lapin yliopistokustannus, Rovaniemi.

Syrjämäki, E. (2013) Mikä on oikeaa tietoa? Turvetuotannon diskurssit paikallisen tiedon näkökulmasta Saarijärven reitillä. Yhteiskuntapolitiikan pro gradu-tutkielma, Jyväskylän yliopisto.

Tilastokeskus (2017a) Suomen virallinen tilasto (SVT): Energian hankinta ja kulutus [verkkojulkaisu]. Tilastokeskus Helsinki. http://www.stat.fi/til/ehk/tau.html. 11.5.2017.

Tilastokeskus (2017b) Avoimet karttapohjat. http://pxnet2.stat.fi/explorer/Avoin/index.html\#story=0. 13.5.2017.

Tupala, A-K. (2014) Sosiaalisten vaikutusten arvioinnin tehostaminen maakuntakaavoituksessa. Ympäristötieteen ja -teknologian pro gradu-tutkielma, Jyväskylän yliopisto.

Vapo (2017) Turvetuotannon vesiensuojeluohjelmat. www.vapo.com/turvetuotantoavastuullisesti/ymparistonsuojelu/ vesiensuojelumenetelma 5.6.2017. 
Liitetaulukko I: Otoksen kuntakohtainen jakautuminen

Appendix table I: Sample distribution by municipality

\begin{tabular}{|l|c|c|}
\hline & Vakituisia asukkaita & Vapaa-ajan asukkaita \\
\hline Kyyjärvi & 300 & 50 \\
\hline Karstula & 425 & 75 \\
\hline Saarijärvi & 650 & 150 \\
\hline Uurainen & 300 & 50 \\
\hline
\end{tabular}

Liitetaulukko 2:Vastanneiden kotikuntajakautuma

Appendix table 2. Distribution of respondents by municipality

\begin{tabular}{|l|c|c|}
\hline Kunta & Vastanneiden määrä (vastaus \%) & Osuus vastanneista \% \\
\hline Kyyjärvi & $47(15,7)$ & 9,8 \\
\hline Karstula & $93(21,9)$ & 19,5 \\
\hline Saarijärvi & $139(21,4)$ & 29,1 \\
\hline Uurainen & $56(18,7)$ & $1 \mathrm{I}, 7$ \\
\hline Vapaa-ajan asukas, jonka kotikunta on muualla & $133(40,9)$ & 27,8 \\
\hline Puuttuva tieto & 10 & 2,1 \\
\hline
\end{tabular}

